\title{
UAVによる空撮と画像解析を用いた被災者捜索技術の開発 \\ Development of a Method for Searching Survivors in Disaster-affected Areas with UAV and Image Analysis
}

\author{
佐藤遼次 ${ }^{1}$. 越村俊一 ${ }^{2}$
}

\author{
Ryoji SATO and Shunichi KOSHIMURA
}

\begin{abstract}
When natural disasters strike, such as tsunamis or floods, people are sometimes isolated in disaster-affected areas. In this study, the authors propose a method of searching survivors with UAV (Unmanned Aerial Vehicle) to show usefulness and problems when applying to search and rescue operations. First, with the help of the UAV, they took pictures of humans surrounded by conditions similar to disaster-affected areas. Second, they explored possibility of human detection from those images, using object-based image analysis. Through the study, they found that their UAV observation potentially works well for searching survivors in disaster-affected areas.
\end{abstract}

\section{1. 序論}

大規模な災害の被災地では，被災者が孤立してしまう 事態が頻繁に発生する。孤立した被災者の多くは，建物 の上階・屋上や高台などで救助を待っており，彼らの早 期発見は人命救助の観点から極めて重要である. 現在は 有人のヘリコプターによる捜索・救助が行われている が，より小型かつ簡便な無人航空機（UAV=Unmanned Aerial Vehicle) が「捜索」を担い, 有人機が「救助」を 担うことで，ょり円滑な救命活動の展開が期待できる. 現状でのUAVによる捜索は，例えば炭田ら（2011）で述 べられているように機能や法制度の面で課題が多く, 現 場に適用するにはまだ時間がかかるものの，UAVによる 被災者捜索の手法を確立していくことは，災害対応にお けるUAVの有效性やそのために必要な機能を示すことに 繋がる.

既往の研究事例を整理すると, 画像や映像から人を検 出するための研究は古くから行われているが，UAV等を 用いて上空から人を撮影した場合についての検証は少な い.たとえば, Gaszczakら (2011) やDoherty・Rudol （2007）は，UAVに熱赤外ビデオカメラを搭載して人を 撮影し，これが人の検出に有効であることを示した。ま たOreifejら（2010）やReillyら（2010）は, UAVから撮 影した光学画像から人の検出を試み, 一定の成果を上げ ている.

一方, 既往の研究では, 特に災害時の状況を想定した 検証がほとんど行われていないという課題がある。災害 時の利用を目的とするには，特に撮影環境については災 害時を想定した環境で行う必要がある。 その他にも人の

1 学生会員

2 正会員

東北大学大学院工学研究科

博 (工)

東北大学教授 災害科学国際研究所
姿勢や服装, UAVの高度, カメラの角度といった条件に よっても見え方は異なる.さらにセンサの種類も, 光学 カメラや光学ビデオカメラ, 熱赤外カメラ等の中から, 状況に応じて適したものを選ぶ必要がある。そのため, こうした撮影条件とそれに応じた最適な検出手法を解明 することは重要な課題である.

本研究の目的は, UAVを用いた被験者の撮影と画像解 析を通して，災害時の被災地探索に扔けるUAVの有効性 を実証することである，本研究では，災害時を想定した 撮影条件の下でUAVから被験者を撮影し, 画像解析によ る被験者の検出を試みる。具体的には, 撮影場所, UAV の高度, カメラの角度, カメラの種類, 被験者の服装と 姿勢の計 $6 つ の$ 条件を設定し, 各条件の違いに応じた被 験者検出の検証を行う。さらに, 撮影により得られた画 像にオブジェクトベース画像解析を行うことで, 人体の 特徴の検出を試みる。そしてその精度を評価することで, 被災者捜索に効果的な解析手法を検討するとともに，そ の有効性について撮影条件との関連から論ずる.

\section{2. 撮影条件の設定と人の撮影}

\section{(1) UAVの諸元}

本研究で使用したUAVは, 独Ascending Technologies社 製AscTec Falcon 8である。概観を図-1に，主な諸元につ いて表-1に示す。本機は, 予め飛行経路と撮影ポイント を設定しておくことで, GPS制御により自動で飛行と撮 影を行うことが可能である.

\section{(2) 撮影条件の設定}

撮影場所として, 仙台市宮城野区蒲生から2箇所を選 定した. 1籄所は水溜りが点在し, 雑草が生い茂ってい る湿地帯である，元々は水田だった場所だが，東日本大 震災以降は湿地帯となっている状況であり, 水域の撮影 


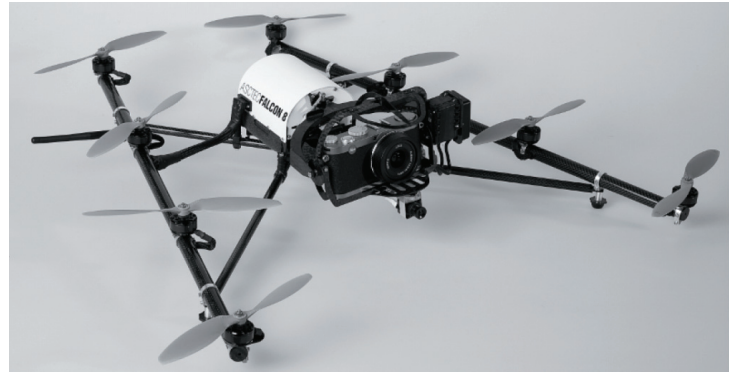

図-1 使用したUAV : AscTec Falcon 8

表-1 使用したUAVの諸元

\begin{tabular}{c|c}
\hline 重量 & $1.8 \mathrm{Kg}$ \\
\hline サイズ & $0.85 \mathrm{~m} \times 0.85 \mathrm{~m} \times 0.15 \mathrm{~m}$ \\
\hline 最大ペイロード & $500 \mathrm{~g}$ \\
\hline 飛行可能時間 & 15 分 \\
\hline 推奨飛行距離 & 半径 $300 \mathrm{~m}$ \\
\hline 耐風性 & $10 \mathrm{~m} / \mathrm{s}$ \\
\hline 耐水性 & なし \\
\hline
\end{tabular}

および周囲と人との識別が容易な環境での撮影を目的と して選定した。もう1つは，東日本大震災により発生し た瓦礫が集積された場所である，自動車や電車などの大 きなものから，金属片やプラスチック片などの小さなも のまで，様々な色・大きさの瓦砂が散らばっている．津 波被災時において周囲に雑多な物が散乱しているよう な，人に注目することが難しい環境での検証を目的とし て選定した。

実際の被災者の服装には様々なものが考えられるが， 本研究では服の色による見え方の違いのみを検証の対象 とした．被験者として6人に協力してもらい，赤，水色， 枯草色の上着を 2 着ずつ着て, 立った状態で腕は身体の 横に付け，目線が正面前方を向くよう姿勢を統一した

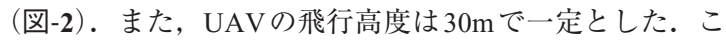
れは，空撮用として本UAV機を使用するに当たり，安全 性を考慮して定められた最も低い高度である. カメラの 角度については, 地上に対して直下 90 度および斜め 45 度の 2 パターンで撮影した。 また本研究では, 光学カメ ラと近赤外カメラの 2 種類を用いて撮影を行った. 光学 カメラは株式会社リコーのGX200を, 近赤外カメラは米 Tetracam 社の ADC Liteを使用した。高度 $30 \mathrm{~m}$ から撮影し た場合の諸元を表-2に示す.

以上の撮影条件の下，湿地带には 6 人，瓦礫域には 5 人の被験者を配置し，2012年11月28日午前に撮影を行 つた.1つの設定条件につき，湿地带では 21 枚，瓦磉域 では 5 枚の撮影を行い，1回の撮影に要した時間はそれ ぞれ9〜10分，1〜2分であった.
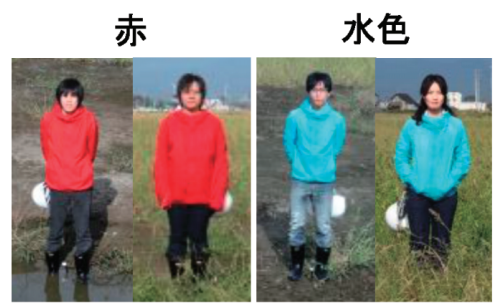

枯草色

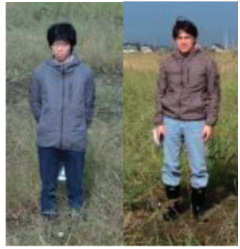

図-2 被験者の服装

表-2 UAVに搭載するカメラの諸元

\begin{tabular}{c|c|c}
\hline & リコー社GX200 & 米Tetracam社ADC Lite \\
\hline 波長帯 & 可視RGB & 近赤外, 可視GR \\
\hline 画素数 & $4000 \times 3000$ pixel & $2048 \times 1536$ pixel \\
\hline 分解能 & $1.1 \mathrm{~cm} /$ pixel & $1.1 \mathrm{~cm} / \mathrm{pixel}$ \\
\hline 撮影範囲 & $43.3 \times 32.5 \mathrm{~m}$ & $23.3 \times 17.3 \mathrm{~m}$ \\
\hline
\end{tabular}

\section{（3）撮影画像の分析}

光学カメラで撮影した画像の一例を図-3に示す，目視 によりこれらの画像を分析した結果, 湿地帯の場合, 赤 や水色のように背景から際立った色の服であれば, 特に カメラ角 45 度の場合, 被験者の識別は十分に可能であっ た. 一方で瓦磁域の場合は, いずれのカメラ角, 服の色 であっても，瓦礫に囲まれた中から被験者を識別するの は難しいことが確認できた。最後に 2 地点に共通する特 徵として, 身体の影が挙げられる. 特にカメラ角 90 度の 場合には, 影が小さな瓦礫と重なっていても認識するこ とが可能であった。

以上の結果から，目視だけで被験者を認識するのは困 難な場合があること, 機械的に人の位置を特定すること で，目視による見落としを補完する手法が必要であるこ とが確認された。 また, カメラ角 45 度で撮影した光学画 像からは人の上半身を, 90 度で撮影した光学画像からは 人の影を検出できる可能性が高いことがわかった。次に， 近赤外カメラで撮影した画像の一例を図-4に示す．画像 が明るいほど近赤外線の反射が強く, 暗いほど弱いこと を表している．頭や顔の部分では共通して反射が弱いこ とが確認できたが，それ以外では同じ上着であっても反 射の強さに違いが見られた。したがって，近赤外線を人 の検出に利用するのは難しいことがわかった。

\section{3. 画像解析による人の特徴の検出}

解析対象画像にオブジェクトベース解析を適用するこ とで, 画像から被験者の上半身㧍よび影の検出を試みる. 解析には画像解析ソフトウェア「ENVI 5.0」の機能の 1 つである「Rule-Based Classification」を使用した。なお， 画像 1 枚当たりの解析に要した時間は 3 分程度である. 
表-3 セグメンテーションの結果

\begin{tabular}{|c|c|c|c|c|c|c|}
\hline & 撮影場所 & 対象画像 & 検出人数 & [Scale Level, Merge Level] & 精度 & 合計精度 \\
\hline \multirow{2}{*}{ 上半身 } & 湿地帯 & 6枚 & 6人 & {$[40.0,99.9]$} & $6 / 6$ & \multirow{2}{*}{$11 / 11$} \\
\hline & 瓦礫域 & 1枚 & 5人 & {$[40.0,95.5]$} & $5 / 5$ & \\
\hline \multirow{2}{*}{ 影 } & 湿地帯 & 6枚 & 6人 & {$[25.0,99.9]$} & $5 / 6$ & \multirow{2}{*}{$9 / 11$} \\
\hline & 瓦礫域 & 2枚 & 5人 & {$[27.0,99.5]$} & $4 / 5$ & \\
\hline
\end{tabular}

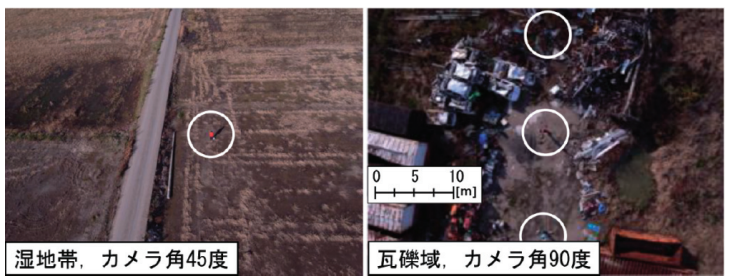

図-3 光学カメラでの撮影により得られた画像 (丸は被験者の位置を示している)
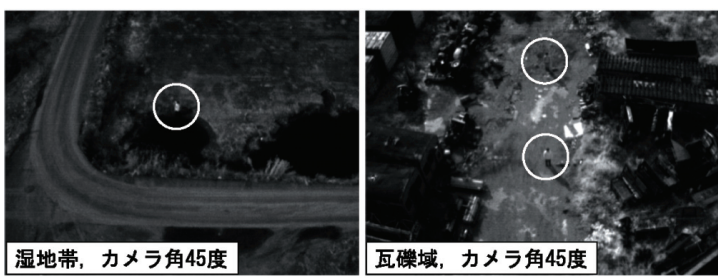

図-4 近赤外カメラでの撮影により得られた画像 (丸は被験者の位置を示している)

\section{（1）解析対象画像の準備}

撮影画像を分析した結果から，上半身の検出にはカメ ラ角 45 度で撮影した光学画像を, 影の検出にはカメラ角 90 度で撮影した光学画像を用いることとした。なお湿地 帯の画像に関しては，被験者を中心に4分の1のサイズ にトリミングしてから解析を行なった。 これは，本来撮 影の対象としていなかった人や湿地帯とは無関係な瓦礫 等が画像の隅に写っていたため，トリミングによってこ れらを除く必要があったためである。

(2) 画像のセグメンテーション

まず最初のステップとして，画像のセグメンテーショ ンを行う。画素值の変化の大きさに基づいて画像を微小 領域に分割した後，空間的関係性の強さに応じてそれら を統合することで，検出対象の輪郭を良好に再現した画 素の集合，即ちオブジェクトの形成を図る。これらの分 割と統合の処理は，それぞれ Scale Levelと Merge Level と いう2つのパラメータによって支配され，共に0から 100 の間で值を設定する必要がある。なおENVI 5.0ではこれ らのパラメータを設定するに当たり，それぞれ使用する アルゴリズムを選択する，本研究では，初期設定である EdgeおよびFull Lambda Scheduleを採用した。

最適なパラメー夕の設定值を解明するため，次の手順 でパラメータスタディを行った。まずMerge Levelを0

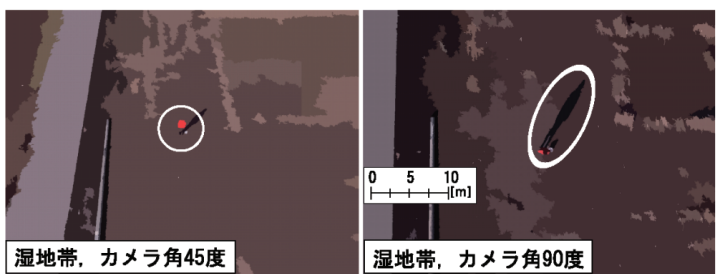

図-5 セグメンテーション後の画像

(左：上半身が対象，右：影が対象）

（即ち全く統合を行わない）に固定した上でScale Level を段階的に変化させ，検出対象に対して最適な画像の分 割の度合いをある程度絞り込む. 次にMerge Levelを段階 的に変化させ，先ほど絞り込んだScale Levelの值と組み 合わせた場合の結果を逐次出力し，それらを比較検討す る.これにより，対象の輪郭を最も良好に再現する「分 割」と「統合」の組み合わせを検討した.

その結果, 表-3に示す設定值を得た. また, セグメン テーションにより得られた画像の一例を図-5に示す。結 果として，上半身については 11 人全て，影については 11 人中 9 人という精度で, オブジェクトの形成に成功した. 影のオブジェクトを形成できなかった場合については， 影が投影されていた地面の色が暗く，影と地面の画素值 に差が無かったためにこれらが統合されてしまったと考 えられる。

\section{（3）オブジェクト分類による特徴の検出}

次にオブジェクト分類を行い，七グメンテーション後 の画像から任意のオブジェクトを検出する.オブジェク 卜分類は，各オブジェクトの画素值 (Spectral), 形状 (Shape), 質感（Texture）という3 種類の情報に対応した パラメータについて, 検出対象に応じた閯值を設定する ことで任意のオブジェクトを抽出する処理である．本研 究ではこのうち形状 (Shape) に着目し, 上半身のオブ ジェクトおよび影のオブジェクトの検出を試みた。

上半身のオブジェクトについて観察したところ，周囲 と区別できるような明確な形状的特徴は見られなかっ た。そのため，使用可能なパラメータについて一つ一つ 有効性を検証し, 効果的なパラメータの特定を試みた. その結果，オブジェクトを構成するピクセル数 (Area), 真円度 (Roundness), 凸状性 (Convexity) という3つの パラメータが特に有効であるとわかった。これらのパラ 
表-4 上半身の検出に用いたパラメータおよび設定した閾值

\begin{tabular}{c|c|c}
\hline & 湿地帯 & 瓦礫域 \\
\hline ピクセル数(Area) & $1079-1840$ & $798-2498$ \\
\hline 真円度(Roundness) & $0.53-0.81$ & $0.50-0.85$ \\
\hline 凸状性(Convexity) & $1.35-1.91$ & $1.29-1.63$ \\
\hline
\end{tabular}

メータについて，セグメンテーションを行った全ての画 像から上半身を漏れ無く検出できるよう閾值を検討し た。設定した閾值の值を表-4に，検出結果の画像を図-6 に示す.

被験者の影のオブジェクトの検出では, 画像中で影が 伸びている方向にまず着目した。これは太陽の方位に応 じて決まるため，撮影した日時と被験者の位置さえわか れば算出可能である.さらに，本研究ではUAVが常に一 定の方向を向いた状態で撮影しているため, 画像中にお ける影の方向も全て一定として求めることができる. そ こで第1の特徴として, 画像の横軸に対してオブジェクト の長軸方向がなす角度を表すパラメー夕（Main-Direction） を採用し，上述した情報を基に閾值を計算した。

まず画像の撮影日時は，湿地帯では2012年 11 月 28 日 午前 9 時 8 分, 瓦碟域では午前 10 時 6 分として統一した。 被験者の位置については, それぞれ各被験者の位置の中 心をとり，湿地带では北緯 38 度 14 分 41.58 秒, 東経 140 度 59 分 46.88 秒, 瓦礫域では北緯 38 度 14 分 38.78 秒, 東 経 140 度 59 分 38.80 秒とした. 撮影時におけるUAVの向 きは, 湿地帯では北から見て西に 65 度の方向, 瓦砂域で は155度の方向であった。以上の值から画像中の影は, 湿地帯では画像の横軸から時計回りに約 123 度の方向, 瓦礫域では44度の方向に伸びていると計算された.

次に影の持つ特徴として, 影の長さに着目した。影の 長さは人の身長によって差が生じるものの, 身長が決ま ればあとは太陽の仰角だけを用いて計算が可能である. したがって, 人の身長にある程度幅を持たせて計算する ことで, 複数人の検出に有効な闇值を設定できると考え た、そこで第2の特徴として, オブジェクトの長軸方向 の長さをピクセル数で表したパラメータ（Major-Length） を採用した。

太陽の仰角は方位と同じく, 撮影の日時と被験者の位 置から算出できる，先程の值を用いて計算した結果，湿 地帯での仰角は 19.0 度, 瓦砂域では 24.8 度と求まった。 画像の分解能を $1.1 \mathrm{~cm} / \mathrm{pixel}$ で一定とし, 今回の被験者の 身長である $163 \mathrm{~cm}$ から $172 \mathrm{~cm}$ までの人を検出対象として, 式（1）により画像中における影の長さを計算した.

$$
\text { 影の長さ }[\mathrm{pixel}]=\frac{\text { 身長 }[\mathrm{cm}]}{\tan (\text { 仰角 })} \div 1.1[\mathrm{~cm} / \mathrm{pixel}] \cdots(1)
$$

以上 $2 つ$ の゚ラメータについて計算した值を参考に,
表-5 影の検出に用いたパラメータ, 閾值の計算值と設定值

\begin{tabular}{c|c|c|c|c}
\hline & \multicolumn{2}{|c|}{ 湿地帯 } & \multicolumn{2}{c}{ 瓦砂域 } \\
\hline & 計算值 & 設定值 & 計算值 & 設定值 \\
\hline 角度(Main-Direction) & 123 & $118-133$ & 44 & $38-57$ \\
\hline 長さ(Major-Length) & $416-447$ & $422-462$ & $304-321$ & $278-395$ \\
\hline 比率(Elongation) & - & $2-8$ & - & $2-6$ \\
\hline
\end{tabular}

表-6 検出の精度

\begin{tabular}{c|c|c}
\hline & 検出精度 & 誤検出数 \\
\hline \multirow{2}{*}{ 上半身 } & 湿地帯 $: 6 / 6$ & 湿地帯 $: 0-3$ 個 \\
\cline { 2 - 3 } & 瓦礫域 $: 5 / 5$ & 瓦礫域: 62個 \\
\hline \multirow{2}{*}{ 影 } & 湿地帯 $: 4 / 6$ & 湿地帯 $: 0$ 個 \\
\cline { 2 - 3 } & 瓦礫域 $: 4 / 5$ & 瓦礫域: 0 個 \\
\hline
\end{tabular}

全ての影のオブジェクトを漏れ無く抽出できるよう閾值 の設定を行った.さらに誤検出を除くため，オブジェク トの長軸と短軸の長さの比率を表すパラメータ (Elongation) を追加し, パラメータスタディにより閾值 を設定した.

閾值の計算值および実際に設定した值を表-5に，検出 結果の画像を図-7に示す.

\section{(4) 検出の結果と考察}

各特徴検出の精度について, 表-6に示す。

上半身の検出では，結果として全ての上半身のオブジ エクトを検出することに成功した，一方で，湿地帯では 最大で3つ，瓦砂域では非常に多くの誤検出が見られた. このことから，このように様々な形や大きさの物が集積 された環境では, 誤検出を完全に除くのは困難であるこ とがわかった.

影の検出については，Main-Direction，Major-Length共 に計算值から若干前後に幅を持たせることで，1つを除 き全ての影のオブジェクトを検出することができた.さ らにElongationを加えたことで, 誤検出を完全に無くす ことに成功した，検出できなかった1つの影については, 影が地面の段差に沿って伸びていたため, 上空から見た 長さが極端に短くなったことが原因と考えられる.

上半身の検出では全てのオブジェクトを漏れ無く検出 できたという点で, 影の検出よりも良好な結果が得られ た.しかしながら, 誤検出という点では影の検出の方が 優れており，1つの誤検出も含まずに検出することがで きた.上半身検出における誤検出を減らす方法としては, 画像中で検出を行う範囲を限定することが考えられる. 今回は 1 枚の画像から 5 名の被験者全てを検出できるよ うに闇值を設定したが, 斜め視の撮影であるため手前側 の被験者は大きく, 反対に奥側の被験者は小さく写って いる. それにより各上半身を構成するピクセル数も変わ 

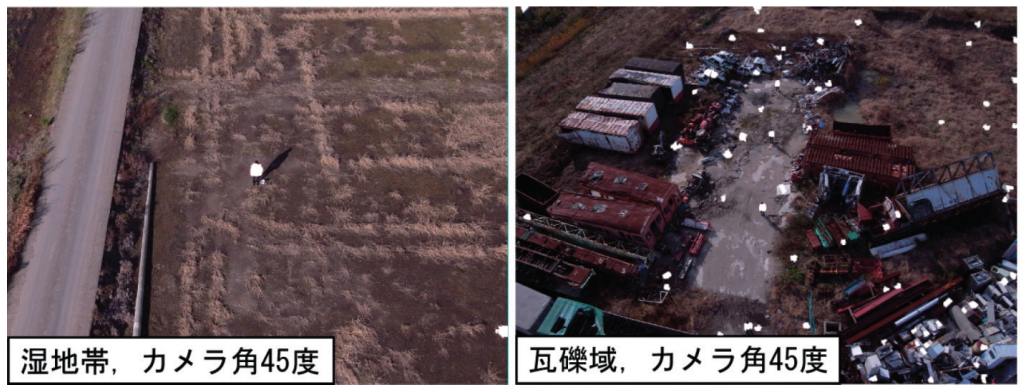

図-6 上半身の検出結果（白色が検出されたオブジェクトを示している）
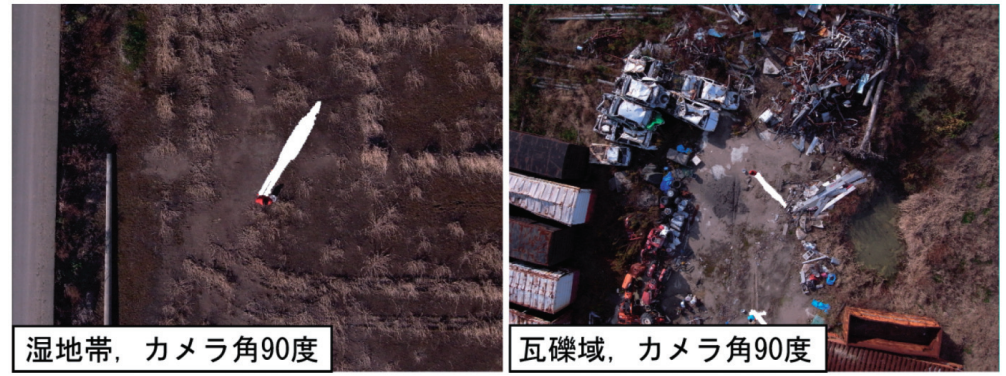

図-7＼cjkstart影の検出結果（白色が検出されたオブジェクトを示している）

ってくるため，形状的特徵のばらつきが大きくなり，結 果的に誤検出も多くなったと見られる，そのため，検出 範囲を適切に限定してやることで誤検出を減らせる余地 があると考えられる。

\section{4. 結論}

本研究では，災害発生後を想定した撮影条件の下で UAVを用いて被災地を撮影し，画像解析による人の特徵 検出と位置の特定を試みることで，被災者を捜索するた めの手法を提案した。

画像の撮影角度に応じて人の上半身および影にそれぞ れ着目し，オブジェクトベース画像解析によってそれら を機械的に検出するために最適なパラメー夕設定や閾值 を明らかにすると共に，検出の精度についても評価を行 った。その結果，上半身については，一様な色の服を着 ている場合であれば，カメラ角 45 度で撮影した光学画像 から，被災者を漏れ無く検出できることを確認した。影 に着目した場合，日照条件や地面の色等によって精度が 左右されるものの，形成したオブジェクトについては誤 検出無く, 11名中 8 名という正解率で検出に成功した。

以上より，限られた条件の下ではあるが，簡易なデジ タルカメラを搭載したUAVを被災者の捜索に活用できる ことを実証することができた。今後は光学カメラ以外の センサを導入することで，様々な条件に応じて最適な被 災者捜索手法の開発を行なっていく必要がある。
謝辞：本研究の実施には, 科学研究費補助金（課題番 号：24651195)，東北大学総長裁量経費，および東北大 学災害科学国際研究所 特定プロジェクト研究の補助を受 けた。ここに記して謝意を表する。

\section{参 考 文 献}

炭田潤一郎・鈴木真二 · 東野伸一郎 - 西脇英彦 - 満武勝嗣 - 山 下敏明・渡邊邦一 (2011) : 実用的な災害監視小型無人機の 開発について，飛行機シンポジウム講演集 (CD-ROM), 49 卷, $1 \mathrm{~A} 3$.

日本建築学会 (1978): 建築設計資料集成 1 環境, pp. 51.

野里雅彦・中西弘明・野波健蔵・ 川端邦明 - 田所諭 - 三浦憲二郎 (2007)：上空からの情報収集ミッションユニット（上空 $\mathrm{MU})$, 文部科学省大都市大震災軽減化特別プロジェクト平 成 18 年度成果報告書, pp. 31-91.

Doherty, P. and P. Rudol (2007) : A UAV Search and Rescue Scenario with Human Body Detection and Geolocalization, Lecture Notes in Computer Science (including subseries Lecture Notes in Artificial Intelligence and Lecture Notes in Bioinformatics) 4830 LNAI, pp. 1-13.

Gaszczak, A., T. P. Breckona and J. Han (2011) : Real-time People and Vehicle Detection from UAV Imagery, Proceedings of SPIE - The International Society for Optical Engineering 7878, art. no. $78780 \mathrm{~B}$.

Oreifej, O., R. Mehran and M. Shah (2010) : Human Identity Recognition in Aerial Images, Proceedings of the IEEE Computer Society Conference on Computer Vision and Pattern Recognition, art. no. 5540147, pp. 709-716.

Reilly, V., B. Solmaz and M. Shah (2010) : Geometric Constraints for Human Detection in Aerial Imagery, Lecture Notes in Computer Science (including subseries Lecture Notes in Artificial Intelligence and Lecture Notes in Bioinformatics) 6316 LNCS (PART 6), pp. 252-265. 